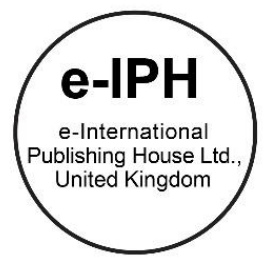

\title{
Designing Alternative Housing in an Old Context: Zargandeparsh, Tehran
}

\author{
Zohreh Yousefi ^*${ }^{\star}$, Seyed Bagher Hosseini ${ }^{1}$, Seyed Abbas Yazdanfar ${ }^{1}$, Saeid Norouzian-Maleki 2 \\ ${ }^{1}$ School of Architecture and Environmental Design, Iran University of Science and Technology, Tehran, Iran \\ ${ }^{2}$ School of Architecture and Urban Planning, Shahid Beheshti University, Tehran, Iran
}

\begin{abstract}
Today, poor performance in old residential contexts in terms of memorable visual elements reduce the residents' sense of belonging. The study used a combination of qualitative and quantitative research methods. To meet the needs of residents, a questionnaire was distributed among twenty-five experts. Data analysis was performed using fuzzy logic to calculate the weight of each criterion of hierarchical fuzzy (FAHP). According to the findings, the largest weight belonged to social interaction $(0.288)$, physical $(0.205)$ and dependence (0.179). The results showed that social interaction is imperative in increasing the residents' sense of attachment.

(C) 2016. The Authors. Published for AMER ABRA by e-International Publishing House, Ltd., UK. Peer-review under responsibility of AMER (Association of Malaysian Environment-Behaviour Researchers), ABRA (Association of Behavioural Researchers on Asians) and cE-Bs (Centre for Environment-Behaviour Studies, Faculty of Architecture, Planning \& Surveying, Universiti Teknologi MARA, Malaysia.
\end{abstract}

Keywords: Housing; old texture; place; sense of attachment

\section{Introduction}

Today, in the old residential areas, factors such as fine texture, lack of adequate access to vehicles and pavements, overshadow memorable elements in the neighbourhood and ignoring open spaces such as courtyards has decreased residents' interactions, sense of attachment and satisfaction. This incompatibility of old housing with the demands and needs of users has become a serious problem. House renovation is not in agreement with the concepts and principles of today's housing and this mismatch has caused the texture to be evacuated. In phenomenological terms, texture is a tangible phenomenon, including landscapes and monuments that express the personality of the area. Texture has helped human to make their existence meaningful, and it is only alive with human and their sense of belonging (Shultz, 2010). The overall goal of this study is to return residence to the existing homes in one of the old areas of Tehran (Zargandeparch) and to increase the residents' sense of attachment by providing facilities and services, satisfaction enhancement, transparency of the space, suitability and visual fitness of the houses with the current context of the neighbourhood. The present study seeks to answer the following questions: What

\footnotetext{
${ }^{*}$ Corresponding author. Tel.: +0-000-000-0000

E-mail address: yousefi_zohreh@yahoo.com
}

(C) 2016. The Authors. Published for AMER ABRA by e-International Publishing House, Ltd., UK. Peer-review under responsibility of AMER (Association of Malaysian Environment-Behaviour Researchers), ABRA (Association of Behavioural Researchers on Asians) and cE-Bs (Centre for Environment-Behaviour Studies, Faculty of Architecture, Planning \& Surveying, Universiti Teknologi MARA, Malaysia. 
are the main factors affecting the residents' sense of belonging in Zargandeparsh? What are the most important strategies for designing housing templates to increase the residents' sense of belonging?

\subsection{Old residential texture}

The old residential area is a part of the city that has lost its identity due to physical or performance weakness, and cannot develop a sense of belonging among its residents. A residential existing texture comes from natural, human and spiritual phenomena that are understood in the form of order and character. A residential texture has a spatial form which means that it has the concrete structure of the human environment (Shultz, 2010). Reducing the efficiency of each process and lack of care, maintenance and revitalization makes it wear. When urban life decreases in the metropolitan area for any reason and no attempt is made for its revival, urban texture of that city is in the process of exhaustion. Residential textures wearing in the urban context affect the municipal body and also its social and economic activities and leads to a severe decrease in the quality of urban life as well as environmental quality (Andalib, 2008). To get a sense of belonging in the old housing texture, it is necessary to examine the concept of place, human relationship with the place, identity and sense of the site.

\subsection{Concept of place}

A place is a space compatible with meaning (Low \& Altman, 1992; Relph, 1976; Tuan, 1977; Lewicka, 2011). It is a space that is significant for an individuals or a group of individuals. In fact, a place comes from a combination of space and meaning (Harrison and Dourish, 1996). Based on phenomenological definition, it can be argued that the nature of "placing" is specifically against the more general concept of "spacing" (Knez, 2014). a specification that results from the assignment of meaning, social interaction, intertwined with memory and, in short, allocation of identity to the place. A place has been considered as a center of meaning and an area of interest (Tuan, 1977). It is located in human experiences, social relationship, emotions, and knowledge. In the most standard definitions, a place is defined as an outcome of the components of the physical, human activities and social and psychological processes related to its physical properties (Relph, 1976). The nature of a place has a deep relationship with human concepts, perceptions, experiences and social interactions. Therefore, building a meaningful place in the old residential context makes it remarkableand significant for its residents. In addition, the texture, physical knowledge and an understanding of the residents' activities and mental perceptions of the residential texture can play a role in the selection of criteria which affect the enhancement of its residents' sense of attachment.

\subsection{The relationship between human, space and residential context}

What architects create is a potential environment for human behavior and what the person admires is the environment affecting him (Lang, 2007). Cross (2001), based on four years of interviews with people, classified the relationship between humans and place into six groups of biological, psychological, ideological, narrative, commodity and attachment. The priority in human relationships with space is a "natural relationship" and family ties. In "spiritual ties" the person has a sense of belonging and responsibility towards the place, unlike "ideological relationship" which is based on individual opinions. Places described in the story lead to the formation of a fourth type of relationship that is "narrative links". The fifth type is "commodity relations", the chief characteristic of which is "the choice". "Commodity relationship" is based on the comparison of people's image and its physical characteristics (Cross, 2001). Low (1992) considered the relationship between humans and place in terms of six categories of relative, lack of relationship, property, cosmological, pilgrimage, and narrative relationship. In the views of Cross and Low, the biological and relative and also cosmological and ideological relationships include the same concepts, and the sequential relationship is the same in both. The results of these studies reflected the same notions in the relationship between people and place to better understand this relationship.

\subsection{Identity of place}

The concept of identity of a place means its characteristics that distinguish the place from other places and its continuity over time (Lewika, 2008). Any place is concretized based on its very nature in spacing. When a person, due to poor body or 
performance of a residential context, cannot identify it and feel comfortable with the environment where he/she is, the environment and texture are said to be anonymous and the people living in the residential area lack the sense of belonging and satisfaction with their residence and the relationship between the individual and the environment appears to be another concept, a concept that is directly related to identity (Finney\& Jivraj, 2013).

\subsection{Sense of place}

There are two basic approaches in the field of phenomenology and psychology to the definition ofsense of a place. The phenomenological approach is dominant in the literature (Stedmen, 2002). Schultz, Yi-fu Tuan, Edwards, Ralph and Simon are theorists who look at the place from a phenomenological perspective. In the phenomenological approach, a sense of place means non-material features of a site, and it is defined by a concept close to the spirit of the site (Einifar, 2007). Physical perspective of environmental psychology, and emotional interaction between humans and a place are studied as a sense of place in order to achieve greater satisfaction with residence, in addition to strengthening the sense of belonging, attachment to the space, security, identity and authenticity in humans (Haywood, 2014). Schultz defines a place as a space associated with memories and experiences and mood of humans. In his view, "place is for human presence" (Shultz, 1985). Falamki, in a psychological approach, addressed the sense of place as an interaction of the physical relations of the neighbourhood based on an understanding of the spatial behavior of local residents of the textures (Falamaki, 2008). Place includes material and nonmaterial aspects, and by the feeling that it creates for its inhabitants, a kind of belonging to the place is created in people which leads to the identity of the place. This spiritual force is called a sense of setting (Semken \& Freeman, 2008).

Table 1. A review of research related to the human connection and location (source: author)

\begin{tabular}{ll}
\hline Profile\& Author & Profile\& Author \\
\hline Places talent (Shultz,1975). & Location friendship or love the place (Tuan ,1977). \\
Identity place (Proshansky,1983). & Character place (Porshansky ,1978). \\
Sense of Pride and happy (Brown \& Perkins,2003). & Rooted (Chawla, 1992). \\
Character place (Shamai ,1991 \& Steel,1981). & The substantiation of the place (Burdg, 1972). \\
$\begin{array}{l}\text { Emotional connection and meeting fundamental human } \\
\text { needs (place versus lack of place). (Relf,1976). }\end{array}$ & A sense of attachment to place (Altman \& Low, 1992). \\
\hline
\end{tabular}

So researchers' comments in various areas show that three types of interaction between humans and the environment and the sense of a place include cognitive, emotional and behavioural interactions with a place, where, according to the researchers, physical activities and semantic features of a site can influence the formation of these interactions and perceptions of the psychological concept of design (Daneshpour and Charkhchian, 2009)

\subsection{Sense of attachment to the place}

Understanding attachment to the place has been considered by researchers in different fields. In the science of sociology, emphasis is put on how symbolic meaning of place affects the social context of human relationships (Ge and Hokao, 2006). A sense of affection to the place appears from individual and social perceptions, habits and experiences of people (Jiven and Larkham, 2003). A sense of attachment to place has attracted the interest of anthropologists and sociologists to study the relationship between humans and holy places (Mihaylov \& Perkins, 2013). During modern urban developments in the 1950s and 1960s affected by the consequences of the World War and compulsory relocation of persons, the importance of paying attention to the living places of people increased and due to rapid changes in modern life and coordination and harmony with modern life attachment to places has found more relevance in today's studies (Scannell, Gifford, 2009). 
Table 2. A review of research related to the place attachment. (source: Lewicka, 2011)

\begin{tabular}{ll}
\hline Profile & Author \\
\hline Jorgensen, Stedman (2006) & $\begin{array}{l}\text { Comprehensive structural and attitudinal three aspects of attachment to place, depending on the } \\
\text { location and identity of the area consist of three components: affective, cognitive and behavioral } \\
\text { Overview of so far parallel, lines of studies in place attachment, the analytical-quantitative and } \\
\text { the holistic-qualitative }\end{array}$ \\
Patterson, Williams (2005) & $\begin{array}{l}\text { An extensive review of belonging place, its history and methodology with particular emphasis on } \\
\text { the natural places }\end{array}$ \\
Farnum, Hall, Kruger (2005) & $\begin{array}{l}\text { Overview on place belong and show its value for processes of planning } \\
\text { Review on mobility and its impact on site attachment }\end{array}$ \\
Gustafson, (2006) & $\begin{array}{l}\text { Browse linguistic and non-verbal methods to measure the neighborhood, including rules defining } \\
\text { the location }\end{array}$ \\
Trentelman, (2009) & $\begin{array}{l}\text { An extensive research of place, and center Neighborhoods attachment and community unit } \\
\text { Review of place belonging and provide a conceptual framework to organize, conduct a study for } \\
\text { the future }\end{array}$ \\
\hline
\end{tabular}

Gifford believes that components of the sense of attachment including "physical environment", "users" and "attachment process" and the type of interaction and relationship between the individual and the place are also important in the study of attachment (Gifford, 2009). During an investigation into the feeling of attachment, identity and memory of places in old cities, Lewicka found that demographic variables such as length of stay, age and generation affect attachment to place, and the attachment to place does not depend on national identity, but it is related to the place. Lewicka also noted that there is an interaction between attachment to place and identity of place (Lewicka, 2008). Lewicka in a study on the sense of attachment to the place stated that progress mainly happened in the application of the concept of place attachment to levels other than neighbourhood and permanent residence, by introducing a new dimension of attachment to place (paying attention to the physical aspect of the environment) (Lewicka, 2011).This study found the positive role of the meaning of place and changes in the environment that lead to an increase in the quality. Thus, the concept of a sense of attachment, which is a definite link between man and the environment, has been used. This study seeks to determine the importance of selected variables to enhance the sense of attachment among the residents.

Table 3. The variables to enhance the sense of attachment to the residents (source: author)

\begin{tabular}{llll}
\hline Criteria & Sub A & Sub B & Sub C \\
\hline Dependence & Residence time & Satisfaction & Ownership \\
Differentiation & Meaning & Continuity & Identity \\
Social interaction & Personal characteristics & Level relationship & Quality of interaction \\
Physical & Solidarity & Legibility & View \\
\hline
\end{tabular}

\section{Methodology of Research}

To assess the sense of attachment to residents of the old residential area, anthropological studies were conducted with qualitative and survey method. The case of study was Zargandehparsh. The neighbourhoods has an area of 129 acres in Tehran. Areas in the central and northern parts of the place and eastern, southern and western parts were checked regularly. Zargandeh formed has been formed since 1951 in urban areas. Residents are of low economic status. Neighbourhoods have an old texture. Therefore, the research was conducted by a combination of qualitative and quantitative methods. First, semi- 
structured interviews were conducted with residents. Based on the results of the literature review and interviews a questionnaire with 25 items was distributed among twenty five experts on architecture and the collected data were analyzed using the FAHP.

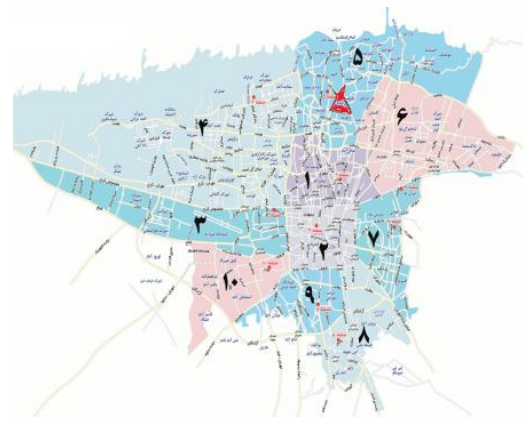

a

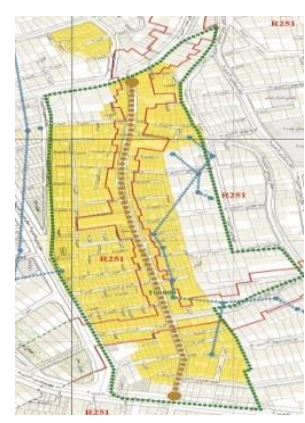

b

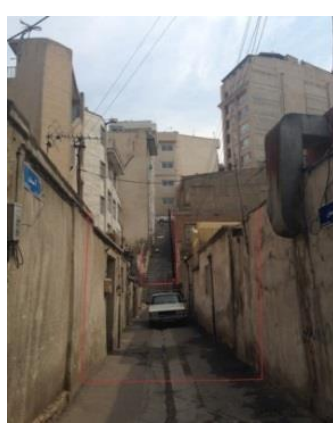

C

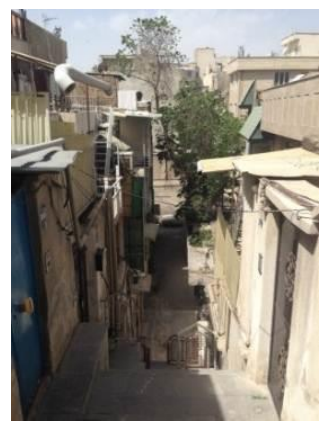

d

Fig. 1. (a) The site of the Zargandeparsh in Teharan; (b) limit of the old texture in Zargandeparsh; (c) The different ratios of Width/Height; (d) A view of the alley; (Source: author)

\subsection{Fuzzy Analytical Hierarchy Process (FAHP)}

Despite the enormous popularity of the hierarchy analysis process, it is often criticized due to its inability to incorporate uncertainty and perceptions of decision-makers towards the accurate numbers. Since the uncertainty is one of the most common characteristics of decision-making issues, FAHP method has been created to meet these problems. This approach lets decisionmakers express their limit priority to fuzzy numbers (Meixner, 2012). In 1996, a method was presented by Chang named Extant Analysis Method (Zhu, Jing, Chang, 1999) the steps of which are described below:

\subsubsection{Hierarchical diagram}

For selection criteria for the decision, a hierarchical chart must be drawn.

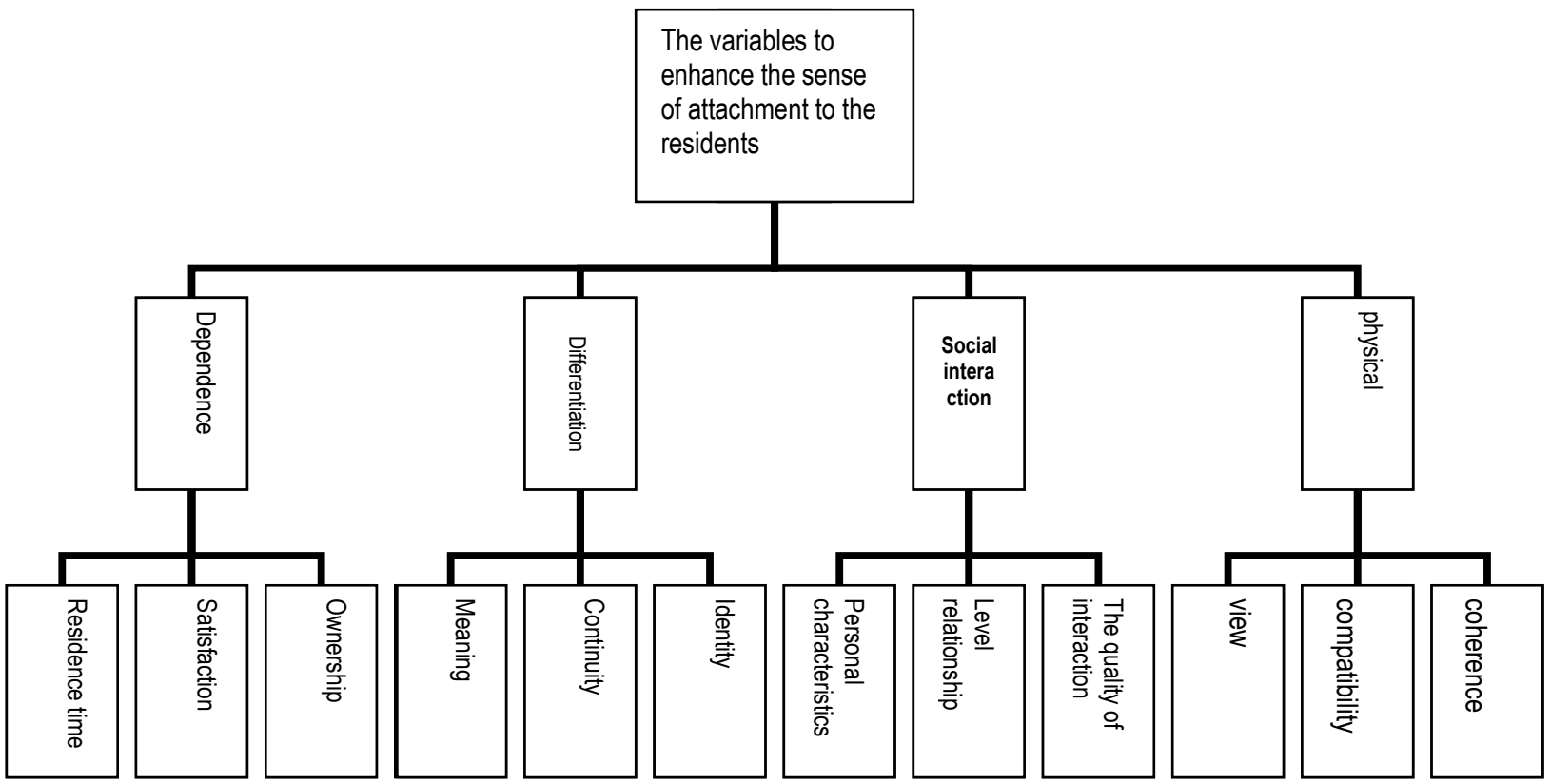


Fig. 2. Hierarchical diagram, selection criteria affecting residents' sense of attachment. (Source: author)

\subsubsection{The definition of fuzzy numbers to make paired comparisons} 3.

For the purpose of making comparisons, we need to define fuzzy numbers and fuzzy. An example of these is given in Table

Table 4. Fuzzy numbers and scales

\begin{tabular}{lll}
\hline A level of fuzzy triangular & Fuzzy value & Preference \\
\hline$(1,1,1)$ & 1 & Exactly equal importance \\
$(2 / 1,1,2 / 3)$ & 2 & The importance too weak \\
$(1,2 / 3,2)$ & 3 & The importance weak \\
$(2 / 3,2,2 / 5)$ & 4 & The importance firm \\
$(2,2 / 5,3)$ & 5 & The importance, so high \\
$(2 / 5,3,2 / 7)$ & 6 & Absolutely importance \\
\hline
\end{tabular}

\subsubsection{Paired comparison matrices using fuzzy numbers}

Paired comparison matrix (A) contains the definitions of fuzzy numbers as follows.

$$
\widetilde{\mathrm{A}}=\left[\begin{array}{cccc}
1 & \widetilde{\mathrm{a}_{12}} & \ldots & \widetilde{\mathrm{a}_{1 \mathrm{n}}} \\
\widetilde{a_{21}} & 1 & \ldots & \widetilde{a_{2 n}} \\
\vdots & \vdots & \ddots & \vdots \\
\widetilde{\mathrm{a}_{\mathrm{n} 1}} & \widetilde{a_{n 2}} & \ldots & 1
\end{array}\right]
$$

2.1.4. $S_{i}$ is calculated by the following equation for each of the paired comparison matrix rows each of which is a triangular fuzzy number.

$$
\mathrm{S}_{\mathrm{i}}=\sum_{\mathrm{j}=1}^{\mathrm{m}} \mathrm{M}_{\mathrm{gi}}^{\mathrm{j}} \times\left[\sum_{\mathrm{i}=1}^{\mathrm{n}} \sum_{\mathrm{j}=1}^{\mathrm{m}} \mathrm{M}_{\mathrm{gi}}^{\mathrm{j}}\right]^{-1}
$$

In which I represent the number of rows and $\mathrm{j}$ represents the number of columns. $\mathrm{M}_{\mathrm{gi}}^{\tilde{j}}$ In this relation represents triangular fuzzy numbers of paired comparison matrices.

$$
\begin{aligned}
& \sum_{\mathrm{j}=1}^{\mathrm{m}} \mathrm{M}_{\mathrm{gi}}^{\mathrm{j}}=\left(\sum_{\mathrm{j}=1}^{\mathrm{m}} \mathrm{l}_{\mathrm{j}}, \sum_{\mathrm{j}=1}^{\mathrm{m}} \mathrm{m}_{\mathrm{j}}, \sum_{\mathrm{j}=1}^{\mathrm{m}} \mathrm{u}_{\mathrm{j}}\right) \\
& \sum_{\mathrm{i}=1}^{\mathrm{n}} \sum_{\mathrm{j}=1}^{\mathrm{m}} \mathrm{M}_{\mathrm{gi}}^{\mathrm{j}}=\left(\sum_{\mathrm{i}=1}^{\mathrm{n}} \mathrm{l}_{\mathrm{i}}, \sum_{\mathrm{i}=1}^{\mathrm{n}} \mathrm{m}_{\mathrm{i}}, \sum_{\mathrm{i}=1}^{\mathrm{n}} \mathrm{u}_{\mathrm{i}}\right) \\
& \quad\left[\sum_{\mathrm{i}=1}^{\mathrm{n}} \sum_{\mathrm{j}=1}^{\mathrm{m}} \mathrm{M}_{\mathrm{gi}}^{\mathrm{j}}\right]^{-1}=\left(\frac{1}{\sum_{\mathrm{i}=1}^{\mathrm{n}} u_{\mathrm{i}}}, \frac{1}{\sum_{\mathrm{i}=1}^{\mathrm{n}} \mathrm{m}_{\mathrm{i}}}, \frac{1}{\sum_{\mathrm{i}=1}^{\mathrm{n}} \mathrm{l}_{\mathrm{i}}}\right)
\end{aligned}
$$

In the above relations, $l_{i}, \mathrm{~m}_{\mathrm{i}}$, and $\mathrm{u}_{\mathrm{i}}$ are respectively $1^{\text {st }}$ to $3^{\text {rd }}$ components of fuzzy numbers.

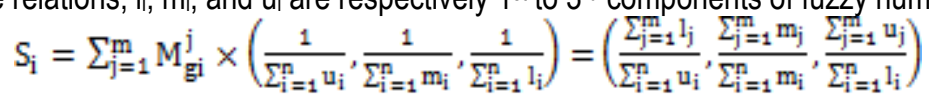


2.1.5. Calculation of the magnitude of Si against each other: Totally, the size of Si against Si is obtained by the following equation:

$$
v\left(S_{i} \geq S_{j}\right)=h g t\left(S_{i} \cap S_{j}\right)=\mu_{s_{i}}(d)=\left\{\begin{array}{lr}
1 & \text { if } m_{i} \geq m_{j} \\
0 & \text { if } u_{j} \geq u_{i} \\
\frac{u_{j}-u_{i}}{\left(m_{i}-u_{i}\right)-\left(m_{j}-u_{i j}\right)} & \text { otherwise }
\end{array}\right.
$$

\subsubsection{Measurement of criteria and options in the paired comparison matrix}

To calculate non-normalized weight of criterion the magnitude of a triangular fuzzy number compared with other triangular fuzzy numbers was calculated and to calculate the minimum size, representing non-normalized weight of criteria, the following equation was used:

$$
\mathrm{d}^{\prime}\left(\mathrm{A}_{\mathrm{i}}\right)=\operatorname{Min} \mathrm{V}\left(\mathrm{S}_{\mathrm{i}} \geq \mathrm{S}_{\mathrm{k}}\right) \quad \mathrm{k}=1,2, \ldots, \mathrm{n}, \mathrm{k} \neq \mathrm{i}
$$

\subsubsection{Calculation of final weight vector}

The final weight vector was obtained by normalizing the weight vector of criterion. Formula 9 were used to derive the final weight vector.

$W=\left(d\left(A_{1}\right), d\left(A_{2}\right), \ldots, d\left(A_{n}\right)\right)^{t}$

\section{Findings}

The main criteria and sub-criteria were provided for experts in the form of a questionnaire aiming at making comparisons. First, the six main criteria were mutually compared. Then the sub-criteria of the main criteria were mutually correlated. The average of maximum response was considered.

Hierarchy and criteria weights

To calculate the weight of each criterion, a paired comparison matrix of criteria was formed and the criteria according to Tables 5 and 6 were compared with the pair. A table of quantitative comparison like Table 3 was used to examine the criterion. To fill these tables, the experts examined the criterion of each level. According to their oral judgment, for each of the six states of Table 3, they put related fuzzy numbers in the tables of paired comparison. After completing the tables by the experts, the weight of criteria, at each level, was calculated using FAHP. The weights were measured through programs written in MATLAB software in which the pressure in each level was specified by entering data into a paired comparison matrix of criterion. Thus, there were enough weights for each criterion as per the number of experts participating in the survey. The final weight of each criterion in each level was obtained by taking the arithmetic mean of the existing weights. The result of these weights is an average of the experts' results.

Table 5. Paired criterions comparison 


\begin{tabular}{lllll}
\hline & Dependence & Differentiation & Social interaction & physical \\
\hline Dependence & $(1,1,1)$ & $(2 / 3,2,2 / 5)$ & $(2,2 / 5,3)$ & $(1,2 / 3,2)$ \\
Differentiation & & $(1,1,1)$ & $(2 / 1,1,2 / 3)$ & $(2 / 1,1,2 / 3)$ \\
$\begin{array}{l}\text { Social } \\
\text { interaction } \\
\text { physical }\end{array}$ & & $(1,1,1)$ & $(2 / 5,3,2 / 7)$ \\
\hline
\end{tabular}

In paired criteria of dependence with other criteria, the social interaction $(2,2 / 5,3)$ is more important than the differentiation $(2 / 3,2,2 / 5)$ and physical $(1,2 / 3,2)$. The experts' further measures were a sense of belonging, social interaction, dependence, physical and differentiation

Table 6. Paired comparison sub-criterions of dependence

\begin{tabular}{|c|c|c|c|}
\hline & Residence time & Satisfaction & Ownership \\
\hline $\begin{array}{l}\text { Residence } \\
\text { time } \\
\text { Satisfaction }\end{array}$ & $(1,1,1)$ & $\begin{array}{l}(1,2 / 3,2 / 7) \\
(1,1,1)\end{array}$ & $\begin{array}{l}(2 / 1,1,2 / 3) \\
(2 / 5,3,2 / 7)\end{array}$ \\
\hline Ownership & & & $(1,1,1)$ \\
\hline
\end{tabular}

In paired sub-criteria of residence time with other sub-criteria, the satisfaction $(1,2 / 3,2 / 7)$ is more important than the ownership $(2 / 1,1,2 / 3)$.According to these experts, the sub-criteria for dependence, satisfaction is more important than the residence and owner ship.

Table 7. Paired comparison sub-criterions of differentiation

\begin{tabular}{llll}
\hline & Meaning & Continuity & Identity \\
\hline Meaning & $(1,1,1)$ & $(2 / 5,3,2 / 7)$ & $(2,2 / 5,3)$ \\
Continuity & & $(1,1,1)$ & $(2 / 3,2,2 / 5)$ \\
Identity & & & $(1,1,1)$ \\
\hline
\end{tabular}

In paired sub-criteria of meaning with other sub-criteria, the identity $(2,2 / 5,3)$ is more important than the continuity $(2 / 5,3,2 / 7)$. According to these experts, the sub-criteria for differentiation, identity is more important than the continuity and meaning.

Table 8. Paired comparison sub-criterions of social interaction 


\begin{tabular}{llll}
\hline & Personal characteristics & Level relationship & Quality of interaction \\
\hline $\begin{array}{l}\text { Personal } \\
\text { characteristics }\end{array}$ & $(1,1,1)$ & $(2 / 5,3,2 / 7)$ & $(2 / 1,1,2 / 3)$ \\
$\begin{array}{l}\text { Level } \\
\text { relationship }\end{array}$ & $(1,1,1)$ & $(2 / 3,2,2 / 5)$ \\
$\begin{array}{l}\text { The quality of } \\
\text { interaction }\end{array}$ & & $(1,1,1)$ \\
\hline
\end{tabular}

In paired sub-criteria of personal characteristics with other sub-criteria, the level relationship $(2 / 5,3,2 / 7)$ is more important than the quality of interaction $(2 / 1,1,2 / 3)$. According to these experts, the sub-criteria for social interaction, level relationship is more important than the quality of interaction and personal characteristics.

Table 9. Paired comparison sub-criterions of physical

\begin{tabular}{llll}
\hline & View & Compatibility & Coherence \\
\hline View & $(1,1,1)$ & $(2 / 5,3,2 / 7)$ & $(2,2 / 5,3)$ \\
Compatibility & & $(1,1,1)$ & $(1,2 / 3,2)$ \\
Coherence & & & $(1,1,1)$ \\
\hline
\end{tabular}

In paired sub-criteria of view with other sub-criteria, the coherence $(2,2 / 5,3)$ is more important than the compatibility $(2 / 5,3,2 / 7)$. According to these experts, the sub-criteria for physical coherence is more important than the compatibility and view.

Table 10. The final weight of the sub-criteria

\begin{tabular}{|c|c|c|c|c|c|c|c|}
\hline \multirow[b]{2}{*}{ physical } & \multirow[b]{2}{*}{ Weight } & \multirow{2}{*}{$\begin{array}{l}\text { Social } \\
\text { interaction }\end{array}$} & \multirow[b]{2}{*}{ Weights } & \multicolumn{2}{|l|}{ Differentiation } & \multirow[b]{2}{*}{ Dependence } & \multirow[b]{2}{*}{ Weights } \\
\hline & & & & & Weights & & \\
\hline coherence & $\mathrm{w}=0.263$ & $\begin{array}{l}\text { Personal } \\
\text { characteristics }\end{array}$ & $W=0.273$ & Identity & $W=0.525$ & Ownership & $W=0.204$ \\
\hline Compatibility & $w=0.163$ & $\begin{array}{l}\text { Level } \\
\text { relationship }\end{array}$ & $W=0.266$ & Continuity & $W=0.168$ & Satisfaction & $W=0.555$ \\
\hline view & $w=0.135$ & $\begin{array}{l}\text { Quality of } \\
\text { interaction }\end{array}$ & $W=0.459$ & Meaning & $W=0.305$ & Residence time & $W=0.240$ \\
\hline
\end{tabular}


In the attachment weight of criterion, in the order of preference, sub-criteria of satisfaction, $w=0.555$ residence time, $w=0.240$ and ownership, $w=0.204$ are preferable. As shown in Table 4, among different sub-criteria, in the order of preference, sub-criteria of identity, meaning and continuity are preferred and identity has more weight $(w=0.525)$. As for the final weight of the sub-criteria of social relations, in the order of priority, the sub-criteria of interaction quality, $W=0.459$ personal characteristics, $W=0.273$ and level of relationship, $W=0.266$ were prioritized. Therefore, in social relations, quality of interaction plays a significant role. With regard to the weight of physical sub-criteria, in the order of preference, sub-criteria of coherence, $w=0.263$ compatibility, $w=0$. 163 and view, $w=0.135$ are preferred.

Table 11. The final weight in the selection criterion to promote a sense of belonging residents

\begin{tabular}{llll}
\hline Social interaction & Dependence & Physical & Differentiation \\
\hline 0.288 & 0.205 & 0.179 & 0.155 \\
\hline
\end{tabular}


The weights of criteria were as follows: the criterion of social interaction has a weight of 0.288 , the criterion of dependence has a weight of 0.205 , the criterion of form has a weight of 0.179 , and the criterion of differentiation weighs 0.155 . Interestingly, social interaction weighed 0.288 that has more weight than the other criterions. Thus, it is plausible to say by taking social interaction and priorities into consideration and considering sub-criteria of quality, interaction in social ties, highlighting the significant elements in the residential context, it is possible to promote the residents' sense of attachment.

\section{Discussion and Conclusion}

The results show that the most important criterion for priority are social interactions $(0.288)$, dependence $(0.205)$, physical (0.179), differentiation (0.155). According to the findings, more attention should be paid to social interaction $(w=0.288)$ with other factors. To achieve this we know that the old context requires place efficiency and quality of interaction between residents. The more an area is capable of providing different levels of human needs, the more individuals communicate with the place and in the upper grades the sense of attachment to the place is created which represents the depth of relationship between people and the place. The destruction of the organization of evocative and visual elements in residential textures will contribute to the transparency and the visual appropriateness of the houses with the current context of the neighbourhood and leads to the formation of a good image in the minds of residents. Social interaction is affected by the activities, culture and communication and social interactions of residents, which brings about mass memory, place efficiency, and presence of residents in the residential textures and enhances the sense of attachment of the residents. The second measure in the sense of belonging is an attachment that can be strengthened concerning the satisfaction of the inhabitants. The third important action to increase the sense of belonging is physical. Therefore, taking into account the physical elements in a place and considering semi-open and open spaces, visual intermediaries can be created in the mental communication of the residents and individuals' interaction with the site. Also by facilitating activities in agreement with the needs of residents, more social connections occur in the place and thus their sense of belonging to a place increases. The results emphasize the importance of social interactions in assessment of the old texture in terms of a sense of belonging. The dependence and physical are other factors affecting the residents' sense of belonging. Differentiation has less impact on the sense of belonging among residents in the old texture. This difference may be rooted in the different appoarches to the use of space. For improving efficiency in the context of the residents, there must be natural elements such as groundwater and natural slope of the land and the optimum use of it for a fountain, and a green space in this neighborhood. Since the residents are low-income groups of society, it is necessary to design their homes in the same area taking into consideration the element of courtyard and create a space for interactions among residents. For the neighborhood and homes, a green space and a meeting space should be considered. Houses should be designed so that privacy is established (separate private spaces, semi-private and public spaces). Considering green space per capita in the house courtyard, and the possibility of a view of the yard by the private, semi-private and public spaces are also important. Courtyard homes not overlooking the adjacent units must be available for residents to increase their sense of belonging to their homes. The results represent the first step in the analysis and evaluation of the residents' sense of belonging in this old residetial area in Iran. The results can be a starting point for the evaluation and review of old residential areas to be considered in the guidelines designed to improve the quality of residential spaces in old textures.

\section{References}

Altman, I., \& Low, S. M. (Eds.). (1992). Place attachment. New York: Plenum.

Andalib, A. (2008). Renovation of old textures. Renovation Organization in Tehran.

Brehm, J. M., Eisenhauer, B.W., \& Krannich, R. S. (2006). Community attachments as predictors of local environmental concern. The case for multiple dimensions of attachment. American behavioral scientist, 50, 142e165.

Brown, B. B., Perkins, D. D., \& Brown, G. (2003). Place attachment in a revitalizing neighborhood: Individual and block levels of analysis. Journal of environmental psychology, 23, $259 \mathrm{e} 271$.

Burdge, R. J., \& Ludtke, R. L., (1972). Social separation among displaced rural families: the case of flood control reservoirs. Social Behavior, Natural Resources, and the Environment. Harper \& Row, New York.

Chawla, L. (1992). Childhood place attachments. Place attachment. New York: Plenum Press.

Cross, J. (2001). What is Sense of place? 12th Headwaters Conference. November 2-4 Westren State College.

Daneshpour, A., \& Charkhchian, M. (2007). Public spaces and factors affecting collective life.Nazar magazine, 7, $19 \mathrm{e} 28$. 
Einifar, A. (2007). The dominant role of general patterns in the design of modern residential Data. 32, 39e50.

Falamaki, M. (2008). The experience of architecture in Iran and the West.

Farnum, J., Hall, T., \& Kruger, L. E. (2005). Sense of place in natural resource recreation and tourism: An evaluation and assessment of research findings. General Technical Report, PNW-GTR-660. United States Department of Agriculture, Pacific Northwestern Research Station.

Finney,N., \& Jivraj, S. (2013). Ethnic group population change and neighbourhood belonging. Urban Studies, 0042098013482497.Chicago.

$\mathrm{Ge}$, Jian; Hokao, \& Kazunori (2006), Research on Residential Lifestyles in Japanese Cities from the Viewpoints of Residential Preference, Residential Choice and Residential Satisfaction. Journal of landscape and urban planning, 78,165e178.

Gustafson, P. (2006). Place attachment and mobility. In N. McIntyre, \& K. E. McHugh (Eds.), Multiple dwelling and tourism: Negotiating place, home and identity (pp.17e31).

Gibson, J. J. (1979/1986). The ecological approach to visual perception. Hillsdale, NJ: Lawrence Erlbaum.

Gifford, R., Scannell, L., Kormos, C., Smolova, L., Biel, A., Boncu, S., et al. (2009). Temporal pessimism and spatial optimism in environmental assessment: An 18-nation study. Journal of environmental psychology, 29, $1 \mathrm{e} 12$.

Gifford, R. (2002). Environmental phychology: Principles and practice, Canada, Optimal Books.

Giuliani, M. V., \& Feldman, R. (1993). Place attachment in a developmental and cultural context. Journal of environmental psychology, 13, $267 \mathrm{e} 274$.

Harrison, S., \& Dourish, P. (1996). Re-place-ing space: The roles of place and space in collaborative systems. Proc. CSCW'96. ACM Press.

Haywood, B. K. (2014). A "sense of place" in public participation in scientific research. Science education, 98(1), 64-83.

Jiven, G., \& Peter L. (2003). Sense of place: Authenticity and character. Journal of urban design 8 (1): 67-81.

Knez, I. (2014). Place and the self: An autobiographical memory synthesis. Philosophical psychology, 27(2), 164192.

Lang, J. (2007). The role of behavioral sciences in environmental design.

Lewicka, M. (2008). Place attachment, place identity and place memory: Restoring the forgotten city past. Journal of environmental psychology, $28,209 \mathrm{e} 231$.

Lewicka, M. (2011). Place attachment: How far have we come in the last 40 years? Journal of environmental psychology 31, $207 \mathrm{e} 230$.

Low, S. M. (1992). Symbolic ties that bind. Place attachment in the plaza. In I. Altman, \& S. M. Low (Eds.), Place attachment (pp. 165e185). New York and London: Plenum Press.

Manzo, L. C., \& Perkins, D. D. (2006). Finding common ground: The importance of place attachment to community participation and planning. Journal of planning literature, 20, 335e 350 .

Meixner, O., 2012. Fuzzy AHP group decision analysis and application for the evaluation of energy sources. Institute of marketing, Vienna, Austria.

Mihaylov, N., \& Perkins, D. D. (2013). Community place attachment and its role in social capital development (pp. 61-74). Routledge: New York, NY, USA.

Norberg Schulz, C. (1975), Meaning in western Architecture, Rizzoli, New York.

Norberg-Schulz, C. (1985) The concept of dwelling: On the way to figurative architecture (New York, Electa/Rizzoli)

Norberg Schulz, C. ( 2010). The concept of dwelling; on the way to figurative architecture.Translated by Amiryar Ahmadi, M.Tehran: Nashr.

Nicotera, N. (2007). Measuring neighborhood: A conundrum for human services researchers and practitioners. American journal of community psychology, 40, $26 \mathrm{e} 51$.

Patterson, M. E., \& Williams, D. R. (2005). Maintain ing research traditions on place: Diversity of thought and scientific progress. Journal of environmental psychology, 25, 361e380.

Proshansky, H. M. (1983). Place-Identity: Physical World Socialization of the Self. Journal of environmental psychology, 3,57-83.

Proshansky, H. M. (1978). The city and self-identity. Environment and behavior, 10, 147-169.

Relph, E. (1976). Place and placelessness. London: Pion Limited.

Scannell, L., \& Gifford, R. (2010a). Defining place attachment: A tripartite organizing framework. Journal of environmental psychology, 30, 1e10.

Semken, S \& Freeman, C. B. (2008). Sense of place in the practice and assessment of place-based science teaching. Science Education 92, pp: $1042-1058$. DOI 10.1002/sce.20279.

Shamai, S. (1991). Sense of place: An empirical measurement. Geoforum, 22, 347e358.

Stedman, R. C. (2003a). Is it really just a social construction?: The contribution of the physical environment to sense of place. Society and Natural Resources, 16, 671e685.

Stedman, R. C. (2006). Understanding place attachment among second home owners. The American behavioral scientist, 50, $187 \mathrm{e} 205$.

Steele, F. (1981). sense of place. Boston: CBI Pub.

Trentelman, C. K. (2009). Place attachment and community attachment: A primer grounded in the lived experience of a community sociologist. Society and natural resources, 22, 191e210.

Tuan, Y.-F. (1977). Space and place: The perspective of experience. Minnesota: The University of Minnesota Press.

Zhu, K. J., Jing, Y., \& Chang, D. Y., 1999. Theory and Methodology, A discussion on extent analysis method and applications of fuzzy AHP. European journal of operational research, Vol 116, pp. 450-456. 